\title{
Immunohistochemical study of neoangiogenesis markers in squamous cell lung cancer
}

\author{
M. M. Baudarbekova \\ Zaporizhzhia State Medical University, Ukraine
}

Key words: lung neoplasms, non-small cell lung carcinoma, squamous cell carcinoma, vascular endothelial growth factor receptor-2, CD34 antigen.

Pathologia 2019; 16 (2), 164-169 DOI: 10.14739/2310-1237. 2019.2.177090

E-mail: baudarbekova@ gmail.com
Aim - to study VEGFR-2 and CD34 immunohistochemical expression in squamous cell lung cancer.

Materials and methods. Pathomorphological and immunohistochemical studies of surgical material from 20 patients, which were treated in ZRCOD because of SCLC, were conducted: 10 patients with SCLC without metastases in regional lymph nodes formed the I group of study and 10 patients with SCLC with metastases in regional lymph nodes formed the II group of study. 10 samples of regional lymph nodes with metastases were also examined (the III group of study). Immunohistochemical study was carried out using antibodies against VEGFR-2 and CD34.

Results. Squamous cell lung cancer is characterized by high VEGFR-2 expression marks, which are typical for I and II groups of study: $115.23(97.35 ; 125.55)$ CUOD, $60.28(50.77 ; 67.19) \%$ and $118.33(110.03 ; 140.23)$ CUOD, $56.56(44.19 ; 67.49) \%$, respectively $(P>0.05)$. At the same time, there is statistically significant difference between the levels and the relative areas of VEGFR-2 expression in the primary tumor and in the metastases in regional lymphatic nodules (RLN) (the last one distinguished by the lower expression marks - $89.67(67.25 ; 100.65)$ CUOD; $50.99(41.65 ; 60.10) \%)$. Tendency to increasing of the number of microvessels in the sequence "non-metastatic squamous cell lung cancer - metastatic squamous cell lung cancer - metastases in RLN" was established: 37.50 (25.00; 54.00$)$ vs 64.50 (42.00; 102.00) vs 95.50 (76.50; 125.00), P< 0.05. Presence of correlations between the following indicators was revealed: the level, the relative area of VEGFR-2 expression and the number of microvessels in non-metastatic squamous cell lung cancer $(r=0.35$ and $r=-0.34$, respectively); the level and the relative area of VEGFR-2 expression ( $r=-0.45$ ), the relative area of VEGFR-2 expression and the number of microvessels in metastatic squamous cell lung cancer $(r=0.43)$; the level and the relative area of VEGFR-2 expression in metastases in RLN $(r=-0.44)$.

Conclusions. VEGFR-2 expression indices decrease from I to III groups of study, while CD34 expression increases in this sequence, moreover, the expression indices of the studied markers correlate in the primary tumor and do not correlate in regional metastases.
Киючові слова: пухлини легені, недрібноклітинна карцинома мегені, плоскоклітинна карцинома, VEGFR-2, CD34.

Патологія. - 2019. T. 16, № 2(46). C. 164-169

\section{Імуногістохімічна характеристика маркерів неоангіогенезу у плоскокиітинному раку легені}

\section{М. М. Баударбекова}

Мета роботи - вивчити особливості імуногістохімічної експресії VEGFR-2 і CD34 у плоскоклітинному раку легені (ПРЛ).

Матеріали та методи. Здійснили патоморфологічне та імуногістохімічне дослідження операційного матеріалу 20 пацієнтів, які отримували лікування в ЗОКОД із приводу ПРЛ. І групу спостереження сформували 10 пацієнтів без метастазів у реґіонарних лімфатичних вузлах, II групу - 10 пацієнтів із метастазами в реґіонарних лімфатичних вузлах. Дослідили також 10 зразків реґіонарних лімфатичних вузлів із метастазами (III група). Імуногістохімічне дослідження виконали, використовуючи антитіла до VEGFR-2 и CD34.

Результати. Плоскоклітинний рак легені характеризується високими показниками експресії VEGFR-2, що властиві I та II групам порівняння: 115,23 (97,35; 125,55) УООЩ, 60,28 (50,77; 67,19) \% і 118,33 (110,03; 140,23) УООЩ, 56,56 $(44,19 ; 67,49)$ \% відповідно ( $p>0,05)$. Виявили статистично значущу різницю між показниками рівня та відносної площі експресії VEGFR-2 у первинній пухлині та в реґіонарних метастазах (останні відрізняються меншими показниками експресії маркера - 89,67 (67,25; 100,65) УООЩ, 50,99 (41,65; 60,10) \%). Встановили тенденцію до збільшення кількості мікросудин у послідовності «неметастатичний плоскоклітинний рак легені - метастатичний плоскоклітинний рак легені - метастази в реґ'іонарні лімфатичні вузли»: $37,50(25,00 ; 54,00)$ vs $64,50(42,00 ; 102,00)$ vs $95,50(76,50 ; 125,00)$, $p<0,05$. Визначили наявність кореляційних зв'язків між такими показниками: рівень, відносна площа експресії VEGFR-2 й кількість мікросудин у неметастатичному плоскоклітинному раку легені ( $r=0,35 \mathrm{ir}=-0,34$ відповідно); рівень і відносна площа експресії VEGFR-2 ( $r=-0,45)$, відносна площа експресії VEGFR-2 й кількість мікросудин у метастатичному плоскоклітинному раку легені ( $r=0,43)$; рівень і відносна площа експресії VEGFR-2 в реґіонарних метастазах $(r=-0,44)$.

Висновки. Показники експресії VEGFR-2 знижуються від I до III групи спостережень, а показник експресії CD34 підвищується в цій послідовності. Показники експресії досліджуваних маркерів корелюють у первинній пухлині та не корелюють у метастазах у реґіонарні лімфатичні вузли.

\section{Иммуногистохимическая характеристика маркеров неоангиогенеза в плоскокиеточном раке легкого}

\section{М. М. Баударбекова}

Цель работы - изучить особенности иммуногистохимической экспрессии VEGFR-2 и CD34 в плоскоклеточном раке легкого (ПРЛ). 
Материалы и методы. Проведено патоморфологическое и иммуногистохимическое исследование операционного материала 20 пациентов, проходивших лечение в ЗОКОД по поводу ПРЛ. I группу наблюдений сформировали 10 пациентов без метастазов в регионарных лимфатических узлах, II группу - 10 пациентов с метастазами в регионарных лимфатических узлах. Также изучили 10 образцов регионарных лимфатических узлов с метастазами (III группа). Иммуногистохимическое исследование проводили с использованием антител к VEGFR-2 и CD34.

Результаты. Плоскоклеточный рак легкого характеризуется высокими показателями экспрессии VEGFR-2, которые свойственны I и II группам наблюдений: 115,23 $(97,35 ; 125,55)$ УЕОП, $60,28(50,77 ; 67,19) \%$ и 118,33 $(110,03 ; 140,23)$ УЕОП, $56,56(44,19 ; 67,49)$ \% соответственно ( $p>0,05)$. Установлена статистически значимая разница между показателями уровня и относительной площади экспрессии VEGFR-2 в первичной опухоли и в регионарных метастазах (последние отличаются меньшими показателями экспрессии маркера - 89,67 $(67,25 ; 100,65)$ УЕОП, 50,99 $(41,65 ; 60,10) \%)$. Отмечена тенденция к возрастанию числа микрососудов в последовательности «неметастатический плоскоклеточный рак легкого - метастатический плоскоклеточный рак легкого - метастазы в регионарные лимфатические узлы»: 37,50 $(25,00 ; 54,00)$ vs $64,50(42,00 ; 102,00)$ vs $95,50(76,50 ; 125,00)$, p < 0,05. Установлено наличие корреляционных связей между следующими показателями: уровень, относительная площадь экспрессии VEGFR-2 и число микрососудов в неметастатическом плоскоклеточном раке легкого ( $r=0,35$ и $r=-0,34$ соответственно); уровень и относительная площадь экспрессии VEGFR-2 ( $r=-0,45)$, относительная площадь экспрессии VEGFR-2 и число микрососудов в метастатическом плоскоклеточном раке легкого ( $r=0,43)$; уровень и относительная площадь экспрессии VEGFR-2 в метастазах в регионарные лимфатические узлы $(r=-0,44)$.

Выводы. Показатели экспрессии VEGFR-2 снижаются от I к III группе наблюдений, а показатель экспрессии CD34 повышается в данной последовательности. Показатели экспрессии изученных маркеров коррелируют в первичной опухоли и не коррелируют в метастазах в регионарные лимфатические узлы.

Despite the improvement of approaches to the diagnosis and treatment of lung cancer (LC), the prognosis for life of patients still remains unfavorable - the indicator of 5 -year survival is less than $20 \%$ [1]. Distant metastases of LC are a key factor in the forecast, determining the tactics of the patient. Squamous cellular lung cancer (SCLC) accounts for about $30 \%$ of all cases of LC, ranking the second in frequency after lung adenocarcinoma. At the same time, SCLC is less prone to distant metastasis in comparison with other histological variants of $L C$, but with a high frequency of metastasis to regional lymph nodes (RLN). The presence of metastases in the RLN is also attributed to prognostically significant factors, therefore, the deepening of knowledge about the mechanisms of lymphogenous dissemination is clinically significant [2].

Based on current literature data, one of the key links in tumor progression and metastasis is neoangiogenesis. There are three main mechanisms that mediate vascular neoplasm formation in cancer: secretion of growth factors by tumor cells that stimulate endotheliocytes; reduced activity of natural angiogenesis inhibitors; angiogenesis mediated by circulating endothelial cell precursor cells [3]. Vascular endothelial growth factor (vascular endothelial cell growth factor, VEGF) is a specific mediator of angiogenesis, the function of which is mediated predominantly by the receptor for vasculo-endothelial growth factor 2 tyrosine kinase activity [4]. Overexpression of VEGF and VEGFR-2 is associated with cancer invasion and metastasis.VEGFR-2 expression is found in endotheliocytes, as well as in cancer cells of a number of tumors (colorectal cancer, breast cancer, etc.). Evaluation of the immunohistochemical expression of VEGFR-2 is currently used to address the issue of treatment with targeted anti-angiogenic drugs. However, the prognostic significance of VEGFR-2 expression by $X$-ray cells is still debated [5]. The mechanisms of interaction of VEGFR-2 with the elements of the tumor microenvironment, in particular, with the stem cell pool, are of considerable interest. In addition, it is known that the expression of VEGFR-2 correlates with the density of microvessels in a number of malignant tumors, predetermining the prognosis [4].

Microvascular density is a parameter for assessing the growth of new blood vessels, which is widely used in studies of a wide range of pathologies, including malignant tumors [6]. It is known that the growth of a malignant neoplasm with a diameter of more than $2 \mathrm{~mm}$ requires the development of its own vascular network. For the purpose of measuring the density of microvessels, markers CD31, CD34, CD105 are traditionally used. In the current literature, no information was found on the difference between the microvessel density indices in cancer, assessed using each of these markers. Probably, the choice of the marker is based on the specifics of the goals and objectives that are pursued in each study [6-8]. CD34 is an intercellular adhesion molecule that is expressed on the surface of a number of cells, including umbilical cord cells, bone marrow cells, mesenchymal stem cells, endothelial progenitor cells, and mature blood vessel endotheliocytes [9]. In a number of works, associative links between microvascular density in LC, assessed by the expression of CD34 and prognostic parameters, such as the stage of the tumor process, the presence of metastases, and the survival rate of patients, have been shown [7-9]. However, the molecular mechanisms that form the basis of tumor progression mediated by neoangiogenesis are still not clarified. Therefore, in the context of studying the mechanisms of SCLC progression, it is important to compare the levels of expression of VEGFR-2 and CD34 in tumor samples without metastases in the RLN, with metastase in the RLN, as well as in the samples of the metastases in the RLN itself, with subsequent analysis of the data.

\section{Aim}

To study the level and relative area of immunohistochemical expression of VEGFR-2 and the number of microvessels (according to CD34 expression) in non-metastatic and metastatic squamous cell lung cancer, and in its metastases to regional lymph nodes.
Ключевые слова: опухоли легкого, немелкоклеточный рак мегкого, плоскоклеточный рак, VEGFR-2, CD34.

Патология. - 2019. T. 16, № 2(46). C. $164-169$ 


\section{Material and research methods}

A pathological and immunohistochemical (IHC) study of the surgical material of 20 patients treated in ZRCOD for SCLC was conducted. Patients were divided into two groups: group I was formed by 10 patients without metastases in regional lymph nodes ( $\mathrm{pT} 1-2 \mathrm{~N}-0 \mathrm{M} 0 \mathrm{G} 1-3)$, group II - 10 patients with metastases in regional lymph nodes (pT1-2N1-2M0G1-3). The exclusion criteria were the presence of distant metastases, as well as the germination of the tumor in adjacent organs. Also 10 samples of RLN with metastases (group III) were examined.

The features of the microscopic structure of SCLC were evaluated in microscopic preparations stained with hematoxylin and eosin. In dewaxed sections, after temperature unmasking and suppressing the activity of endogenous peroxidase, according to standard methods, IHC was performed using polyclonal antibodies VEGFR2 Ab-1 (Thermo Scientific, USA) and monoclonal antibodies CD34 (Clone QBEnd/10; Thermo Scientific, USA) and UltraVisionQuanto Detection imaging system with diaminobenzidine (Thermo SCIENTIFIC, USA). The results of $\mathrm{IHC}$ studies were evaluated by Axioplan-2 microscope (Carl Zeiss, Germany) with magnification $\times 200$. In each case, 5 fields of view were evaluated. In the study of sections stained using antibodies to VEGFR-2, the level and relative area of expression was estimated using photo-digital morphometry [10]. The expression level of IGH markers was expressed in arbitrary units of conditionaloptical density (CUOD) and was graduated as follows: $0-20$ CUOD - negative reaction, 21-50 CUOD - low expression level, 51-100 CUOD - moderate expression, more than 100 CUOD high expression level. The relative area of expression of the markers is the percentage of the number of pixels of immune colored cells to the total number of pixels of the digital photo image. In the study of sections stained with anti-CD34 antibodies, micro vessels were counted according to the method of S. Bosari et al [11].

Statistical processing of the data was carried out using the Statistica ${ }^{\circledR}$ for Windows 13.0 package (StatSoft Inc., license No. JPZ804I382130ARCN10-J). The median $(\mathrm{Me})$ and the lower and upper quartiles (Q1; Q3) were calculated; the comparison between the two groups of observations was carried out using the Mann-Whitney test, between the three groups of observations using the Kruskal-Wallis test; correlation analysis was carried out using Spearman's rank correlation coefficient. Results were considered statistically significant at $95 \%(P<0.05)$.

\section{Results}

As a result of the $\mathrm{IHC}$ study, it was established that membrane-cytoplasmic expression of VEGFR-2 is determined in tumor cells, as well as stromal endotheliocytes of SCLC. Non-metastatic SCLC (Group I observation) and metastatic SCLC (Group II observation) are characterized by high levels of VEGFR-2 expression: the marker expression level is $115.23(97.35$; 125.55) CUOD for non-metastatic and 118.33 (110.03 140.23) CUOD for metastatic SCLC (Fig. 1).

At the same time, the difference between the data obtained for the two groups of observations is not statisti- cally significant $(P>0.05)$. The relative area of VEGFR-2 positive cells is $60.28(50.77 ; 67.19) \%$ in non-metastatic SCLC and $56.56(44.19 ; 67.49) \%$. The difference between the obtained indicators is also not statistically significant $(P>0.05)$. In metastases of SCLC in regional lymph nodes (Group III), the average expression level of VEGFR-2 was set: Me $=89.67(67.25 ; 100.65)$ CUOD. The relative area of VEGFR-2-positive cells in SCLC metastases is $50.99(41.65 ; 60.10) \%$. A comparative analysis using the Mann-Whitney test revealed a statistically significant difference between the medians of the expression level of VEGFR-2 in the II and III groups of observations: 118.33 (110.03; 140.23) CUOD vs 89.67 (67.25; 100.65) $(\mathrm{P}<0.05)$.

Using the Kruskal-Wallis criterion, a comparative analysis of data obtained in three groups of observations was carried out (Fig. 2, 3). The obtained data reflects a tendency to a decrease in the level and area of VEGFR-2 expression in SCLC metastases in regional lymph nodes in comparison with the primary tumor.

As a result of an IHC study, it was found that membrane expression of CD34 is determined in the endothelium of microvascular blood vessels and its metastases, which allows microvessel counting in the field of view of a light microscope (Fig. 4).

The number of microvessels in non-metastatic SCLC is 37.50 (25.00; 54.00), in metastatic SCLC $64.50(42.00 ; 102.00)$, in lung cancer metastases in regional lymph nodes - 95.50 (76.50; 125.00) (Fig. 5). A comparative analysis using the Mann-Whitney test revealed the presence of statistically significant difference between the number of microvessels in non-metastatic and metastatic SCLC, as well as in metastatic SCLC and in its metastases in regional lymph nodes. Thus, the data obtained reflect a significant increase in the number of microvessels in the sequence "non-metastatic SCLC metastatic SCLC - metastasis SCLC in RLN".

A correlation analysis of the relationship between the expression levels of VEGFR-2 and the number of microvessels assessed by CD34 expression (Table 1, 2, 3). In non-metastatic SCLC, a direct medium correlation between the expression level of VEGFR-2 and the number of microvessels was detected $(r=0.35)$ (Table 1$)$, as well as the inverse medium correlation between the relative expression area of VEGFR-2 and the number of microvessels $(r=-0.34)$ (Table 1). There is also an inverse medium relationship between the level and relative expression area of VEGFR-2 in metastatic SCLC ( $r=-0.45$ ) (Table 2), as well as a direct medium relationship between the expression level of VEGFR-2 and the number of microvessels in metastatic SCLC ( $r=0.43)$. In metastasis of SCLC in RLN, there is also an inverse weak force relationship between the level and the relative expression area of VEGFR-2 $(r=-0.44)$ (Table 3). Associations between the expression indices of VEGFR-2 and CD34 in SCLC metastases in regional lymph nodes were revealed.

\section{Discussion}

Neoangiogenesis is a complex process that includes the proliferation of endotheliocytes, the migration and reactivation of progenitor cells, and the remodeling of 

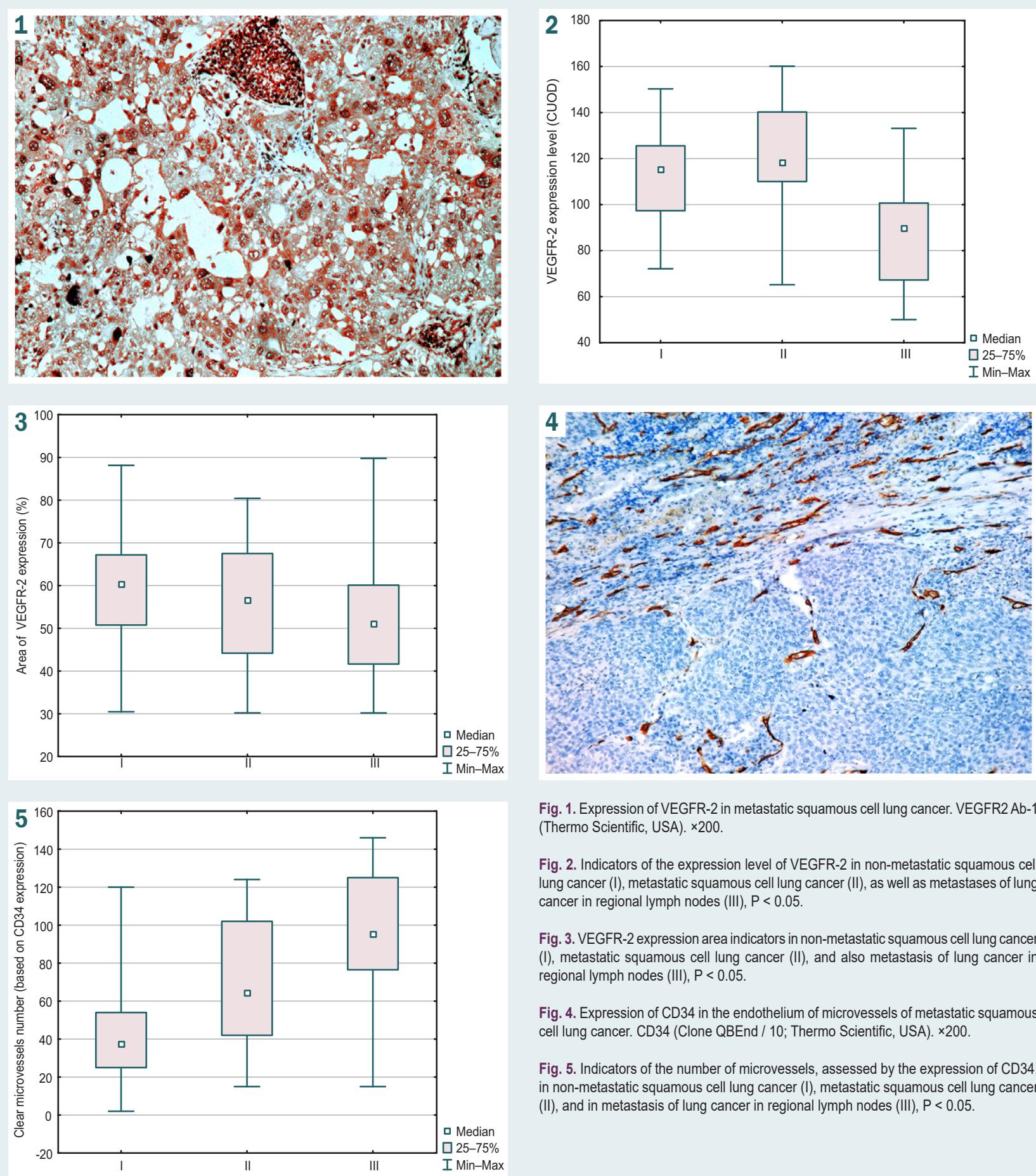

Fig. 1. Expression of VEGFR-2 in metastatic squamous cell lung cancer. VEGFR2 Ab(Thermo Scientific, USA). $\times 200$

Fig. 2. Indicators of the expression level of VEGFR-2 in non-metastatic squamous cell lung cancer (I), metastatic squamous cell lung cancer (II), as well as metastases of lung cancer in regional lymph nodes (III), $\mathrm{P}<0.05$.

Fig. 3. VEGFR-2 expression area indicators in non-metastatic squamous cell lung cancer (I), metastatic squamous cell lung cancer (II), and also metastasis of lung cancer in regional lymph nodes (III), $\mathrm{P}<0.05$.

Fig. 4. Expression of $C D 34$ in the endothelium of microvessels of metastatic squamous cell lung cancer. CD34 (Clone QBEnd / 10; Thermo Scientific, USA). ×200.

Fig. 5. Indicators of the number of microvessels, assessed by the expression of CD34 in non-metastatic squamous cell lung cancer (I), metastatic squamous cell lung cancer (II), and in metastasis of lung cancer in regional lymph nodes (III), $\mathrm{P}<0.05$.

an existing capillary field. Vascular neoplasm in a tumor becomes possible due to hypoxia, which inevitably occurs in conditions of high proliferative activity of cancer cells, stimulates the migration of endotheliocytes and progenitor cells, as well as specific receptors responsible for regulating the proliferation and differentiation of endothelial cells. In addition, molecular genetic abnormalities, that are constantly present in the tumor cells, provide activation of potentially oncogenic signaling cascades, the targets of which are also genes regulators of angiogenesis [3].
According to the results of the study, SCLC is characterized by a high level of membrane-cytoplasmic expression of VEGFR-2. It is type $\mathrm{V}$ tyrosine kinase receptor, which is encoded by the KDR [Kinase insert domain receptor] gene and is expressed predominantly by endothelial cells. VEGFR-2 is activated by vascular endothelial growth factors VEGF-A, $-C$ and $-D$, which leads to the launch of a number of signaling cascades, including MAPK-, PI3Ks-, Akt-cascades, among the targets of which are genes regulating the proliferation and differentiation of endotheliocytes [4,5]. The works of 
Table 1. Correlations between the expression of VEGFR-2 and CD34 in non-metastatic squamous cell lung cancer

\begin{tabular}{l|l|l|l} 
& VEGFR-2(CUOD) & VEGFR-2 (\%) & CD34 \\
\hline VEGFR-2 (CUOD) & 1.00 & -0.06 & $0.35^{*}$ \\
VEGFR-2 (\%) & -0.06 & 1.00 & $-0.34^{*}$ \\
CD34 & $0.35^{*}$ & $-0.34^{*}$ & 1.00 \\
\hline
\end{tabular}

*: statistically significant correlation $(P<0.05)$.

Table 2. Correlations between the expression of VEGFR-2 and CD34 in metastatic squamous cell lung cancer

\begin{tabular}{l|l|l|l} 
& VEGFR-2(CUOD) & VEGFR-2 (\%) & CD34 \\
\hline VEGFR-2(CUOD) & 1.00 & $-0.45^{*}$ & $0.43^{*}$ \\
VEGFR-2 $(\%)$ & $-0.45^{*}$ & 1.00 & 0.24 \\
CD34 & $0.43^{*}$ & 0.24 & 1.00 \\
\hline
\end{tabular}

*: statistically significant correlation $(P<0.05)$.

Table 3. Correlations between the expression of VEGFR-2 and CD34 in metastases into RLN

\begin{tabular}{l|l|l|l} 
& VEGFR-2(CUOD) & VEGFR-2 $(\%)$ & CD34 \\
\hline VEGFR-2(CUOD) & 1.00 & $-0.44^{*}$ & -0.13 \\
VEGFR-2 $(\%)$ & $-0.44^{*}$ & 1.00 & 0.03 \\
CD34 & -0.13 & 0.03 & 1.00 \\
\hline
\end{tabular}

*: statistically significant correlation $(P<0.05)$.

M. Ding et al. (2009) [12], A. M. Deveri et al. (2015) [13] also showed predominantly high levels of VEGFR-2 expression in LC samples. In addition, A. M. Deveri et al. (2015) showed that in normal lung tissue samples, VEGFR-2 expression is observed exclusively in endothelial cells of vessels, while in LC samples, it is also observed in tumor cells [13]. Our work has shown that a high level of expression of VEGFR-2 characterizes SCLC without metastases in the RLN, as well as SCLC with metastases in the RLN, while the regional metastases themselves are characterized by an average (reliably lower) level of marker expression. Analysis of the relative area of expression of VEGFR-2 also reflects a tendency to decrease the expression of VEGFR-2 in regional metastasis of SCLC in comparison with the primary tumor, in addition, in metastatic carcinomas, the expression level of VEGFR-2 is lower than in cases of SCLC without metastases. In the literature [12,13] information was also found that the expression of VEGFR-2 is less in metastatic LC compared to non-metastatic. However, a mechanism explaining the decrease in the expression level of this marker when lymphogenous metastasis is involved has not been described. At the same time, literature data on the expression of VEGFR-2 in regional metastases differ: both relatively large [4] and relatively less marker expression [12,13] are described. Earlier studies of V. O. Tumanskyi et al. also demonstrate an increase in the expression level of the VEGFA marker in cases of non-metastatic and metastatic endometrial adenocarcinoma of the endometrium compared with normal endometrium [14].

This study shows an increase in the number of microvessels, assessed by the expression of CD34, in the sequence "non-metastatic SCLC - metastatic SCLC - regional metastasis SCLC". CD34, a transmembrane glycoprotein encoded by the gene of the same name, is expressed on the membranes of endothelial cells and their precursors, as well as a number of other cells [15]. In the work of Sh. Ikemura et al. (2017) [9] it was found that the number of microvessels assessed by the expression of CD34 sharply decreases in the sequence "primary tumor (SCLC) -micrometastases in RLN", and then significantly increases in macrometastases in RLN, almost comparing with those in the primary tumor. In the work of N. Aramaki et al. (2016) [16] similar data were obtained when studying lung adenocarcinoma and its regional metastases. Based on the fact that this work also revealed a direct statistically significant correlation between the expression of CD34 and E-cadherin, $\alpha$-SMA, CD204, the authors hypothesized that coordination of neovascularization is mediated by an epithelial-mesenchymal transition that cancer cells undergo during the implementation of invasive and metastatic properties. However, the question of the molecular subcellular mechanism and the clinical significance of reducing neoangiogenesis at the stage of the formation of regional lymphogenous metastases of $L C$ remains open.

The data of the correlation analysis indicate a weak inverse association between the intensity and the area of VEGFR-2 expression at the metastatic stage of SCLC (both in the primary tumor and in metastases into RLN). A large area of the vascular network in the tumor tissue means the intensification of the neovascularization process, which is characteristic of the metastatic stage of tumor development. Newly formed vessels contain fewer VEGFR-2 receptors compared to mature vessels [3], which explains the identified association.

In addition, a number of associations were identified between the expression of VEGFR-2 and the number of microvessels assessed by the expression of CD34. Thus, there is a direct weak association between the expression level of VEGFR-2 and the number of microvessels, as well as an inverse weak association between the expression area of VEGFR-2 and the number of microvessels in non-metastatic SCLC. The nature of the established relationship (direct or inverse) is consistent with the established patterns of association between the level and area of VEGFR-2 expression, as mentioned above. The presence of a direct weak correlation between the expression level of VEGFR-2 and the number of microvessels in metastatic SCLC was also found. The mechanism of the relationship between VEGFR-2 and CD34 has not been described for either LC or for other neoplasms. Based on literature data, it can be assumed that the basis of this relationship is laid in signaling cascades mediated by VEGFR-2 and CD34. Thus, it was already mentioned above that VEGFR-2 activates a number of signaling pathways, including MAPK-, PI3Ks-, Akt-cascades. Regarding CD34, it is known that the regulation of the CD34 gene is carried out by transcription factors that are activated by the Wnt and Hedgehod signaling paths. These signaling pathways are involved in the epithelial-mesenchymal transition, which is a key part of the tumor progression [17]. Probably, the change in the characteristics of neovascularization, described in this paper for individual stages of SCLC development, also reflects the different stages 
of the epithelial-mesenchymal transition, and can be very likely to be used to improve approaches to targeted antiangiogenic therapy for SCLC. It is noteworthy that the expression indices of VEGFR-2 and CD34 in the studied metastasis of SCLC in RLN do not correlate. Explaining the mechanisms of neovascularization in SCLC requires further molecular genetic studies in this area, as well as studying the molecular immunohistochemical characteristics of the epithelial-mesenchymal transition to SCLC.

\section{Conclusions}

1. Squamous cell lung cancer is characterized by a high level of expression of VEGFR-2, while metastasis of squamous cell lung cancer in RLN is characterized by middle level of expression, as well as a significantly smaller area of expression of VEGFR-2.

2. The number of microvessels, assessed by the expression of CD34, increases in the sequence "non-metastatic squamous cell lung cancer - metastatic squamous cell lung cancer - metastases in regional lymphatic nodules".

3 . In the primary tumor, there is an association between the expression indices of VEGFR-2 and CD34, while in metastases in regional lymphatic nodules there are no correlations between the studied markers.

Prospects for further research. Taking into account the results of the work carried out, the next stage of the study is to study the transcriptional activity of the KDR gene (encodes VEGFR-2), as well as a parallel molecular genetic and immunohistochemical study of the transcriptional activity of the CDH1, CTNNB1 genes and the E-cadherin, $\beta$-catenin they encode.

\section{Funding}

The study was conducted in the framework of the research work of Zaporizhzhia State Medical University “Early molecular genetic and immunohistochemical prognosis of propensity for progression of lung cancer and digestive organs", № of state registration 0117 U002580 (2017-2019) which is funded by the Ministry of Health of Ukraine.

Conflicts of interest: author has no conflict of interest to declare. Конфлікт інтересів: віАсутній.

НаАійшла Ао редакції / Received: 29.03.2019

Після Аоопрацювання / Revised: 22.04.2019

Прийнято Ао Аруку / Accepted: 13.05.2019

\section{Information about author:}

Baudarbekova M. M., MD, PhD, Associate Professor of the Department of Pathological Anatomy and Forensic Medicine, Zaporizhzhia State Medical University, Ukraine.

\section{Відомості про автора:}

Баударбекова М. М., канА. меА. наук, Аоцент каф. патологічної анатомії і судової медицини, Запорізький Аержавний медичний університет, Україна.

\section{Сведения об авторе:}

Баударбекова М. М., канА. меА. наук, Аоцент каф. патологической анатомии и суАебной медицины, Запорожский

государственный медицинский университет, Украина.

\section{References}

[1] Siegel, R., Ma, J., Zou, Z., \& Jemal, A. (2014) Cancer statistics, 2014. CA: A Cancer Journal for Clinicians, 64(1), 9-29. doi: 10.3322 caac. 21208

[2] Travis, W. D. (2011) Pathology of lung cancer. Clinics in Chest Medicine, 32 (2011), 669-692. doi: 10.1016/j.ccm.2011.08.005

[3] Paduch, R. (2016) The role of lymphangiogenesis and angiogenesis in tumor metastasis. Cellular Oncology (Dordrecht), 39(5), 397-410. doi: 10.1007/s13402-016-0281-9

[4] Holzer, T. R., Fulford, A. D., Nedderman, D. M., Umberger, T. S., Hozak, R. R., Joshi, A., et al. (2013) Tumor Cell Expression of Vascular Endothelial Growth Factor Receptor 2 Is an Adverse Prognostic Factor in Patients with Squamous Cell Carcinoma of the Lung. PLoS One, 8(11), e80292. doi: 10.1371/journal.pone.0080292

[5] Holzer, T. R., Fulford, A. D., Reising, L. O., Nedderman, D. M., Zhang, X. Benjamin, L. E., et al. (2016) Profiling of Vascular Endothelial Growth Factor Receptor Heterogeneity Identifies Protein Expression-defined Subclasses of Human Non-small Cell Lung Carcinoma. Anticancer Research, 36(7), 3277-88.

[6] Kather, J. N., Marx, A., Reyes-Aldasoro, C. C., Schad, L. R., Zollner, F. G., \& Weis, C. (2015) Continuous representation of tumor microvessel density and detection of angiogenic hotspots in histological whole-slide images. Oncotarget, 6(22), 19163-76. doi: 10.18632/ oncotarget.4383

[7] Zhang, J., Ma, X., Li, Y., Song, Y., Ma, G., Huang, J., et al. (2016) Microvessel density as a prognostic factor in non-small cell lung cancer: a meta-analysis. International Journal of Clinical and Experimental Medicine, 9(9), 17676-17689.

[8] Zhao, Y. Y., Xue, C., Jiang,W., Zhao, H. Y., Huang, Y., Feenstra, K., et al (2012) Predictive value of intratumoral microvascular density in patients with advanced non-small cell lung cancer receiving chemotherapy plus bevacizumab. Journal of Thoracic Oncology, 7(1), 71-5. doi: 10.1097/ JTO.0b013e31823085f4

[9] Ikemura, Sh., Aramaki, N., Fujii, S., Kirita, K., Umemura, Sh., Matsumoto, Sh., et al. (2017) Changes in the tumor microenvironment during lymphatic metastasis of lung squamous cell carcinoma. Cancer Science, 108(1), 136-142. doi: 10.1111/cas.13110

[10] Tumanskyi, V. O., Yevsieiev, A. V., Kovalenko, I. S., \& Zubko, M. D. (patentee) (2015) Patent 99314 Ukraina, MPK 2015.01 G01N 21/00 G06K 9/00 Sposib fototsyfrovoi morfometrii imunohistokhimichnykh preparativ [Patent of Ukraine 99314, IPC 2015.01 G01N 21/00 G06K 9/00 The technique of digital morphometry of immunohistochemical slides]. Biuleten, 10 [in Ukrainian].

[11] Bosari, S., Lee, A. K., DeLellis, R. A., Wiley, B. D., Heatley, G. J., \& Silverman, L. M. (1992) Microvessel quantitation and prognosis in invasive breast carcinoma. Human Pathology, 23, 755-761. doi: 10.1016/00468177(92)90344-3

[12] Ding, M., Liu, L., Hu, Ch., Liu, Y., Qiao, Y., \& Jiang, X. (2014) Expression of VEGFR2 and NRP-1 in non-small cell lung cancer and their clinical significance. Chinese Journal of Cancer Research, 26(6), 669-677. doi: 10.3978/j.issn.1000-9604.2014.12.04

[13] Devery, A. M., Wadekar, R., Bokobza, S. M., Weber, A. M., Jiang, Y., \& Ryan, A. J. (2015) Vascular endothelial growth factor directly stimulates tumour cell proliferation in non-small celllung cancer. International Journal of Oncology, 47(3), 849-56. doi: 10.3892/ijo.2015.3082

[14] Tumanskiy, V. A., Chepets, A. V., \& Kamyshnyi, A. M. (2016) Comparative characteristics of the transcriptional activity of $\mathrm{CDH} 1, \mathrm{CTNNB1}$, VEGFA genes and expression of proteins $E$-cadherin, $\beta$-catenin and VEGFA, coded by these genes in metastatic and non-metastatic endometrioid endometrial carcinoma. Pathologia, 2, 13-18. doi: 10.14739/2310-1237.2016.2.81328

[15] Farzam, F., Safaee, M., Oryani, M. A., Razmara, H., Fathee, N., \& Farzam, V. (2017) Endothelial progenitor cells in patients with nonsmall cell lung cancer. Reviews in Clinical Medicine, 4(2), 50-56. doi: 10.22038/RCM.2016.6484

[16] Aramaki, N., Ishii, G., Yamada, E., Morise, M., Aokage, K., Kojima, M., et al. (2016) Drastic morphological and molecular differences between lymph node micrometastatic tumors and macrometastatic tumors of lung adenocarcinoma. Journal of Cancer Research and Clinical Oncology, 142(1), 37-46. doi: 10.1007/s00432-015-1996-0

[17] Sullivan, J. P., Minna, J. D., \& Shay, J. W. (2010) Evidence for self-renewing lung cancer stem cells and their implications in tumor initiation, progression, and targeted therapy. Cancer Metastasis reviews, 29(1), 61-72. doi: 10.1007/s10555-010-9216-5 